\title{
Genetic variation and DNA fingerprinting of durian types in Malaysia using simple sequence repeat (SSR) markers
}

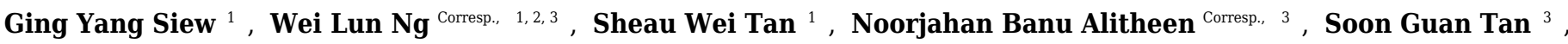 \\ Swee Keong Yeap ${ }^{1,4}$ \\ 1 Institute of Bioscience, Universiti Putra Malaysia, Serdang, Selangor, Malaysia \\ 2 School of Life Sciences, Sun Yat-sen University, Guangzhou, Guangdong, China \\ 3 Department of Cell and Molecular Biology, Faculty of Biotechnology and Biomolecular Sciences, Universiti Putra Malaysia, Serdang, Selangor, Malaysia \\ 4 China-ASEAN College of Marine Sciences, Xiamen University Malaysia, Sepang, Selangor, Malaysia \\ Corresponding Authors: Wei Lun Ng, Noorjahan Banu Alitheen \\ Email address: ng.wl85@gmail.com,noorjahan@upm.edu.my
}

Durian (Durio zibethinus) is one of the most popular tropical fruits in Asia. To date, 126 durian types have been registered with the Department of Agriculture in Malaysia based on phenotypic characteristics. Classification based on morphology is convenient, easy, and fast but it suffers from phenotypic plasticity as a direct result of environmental factors and age. To overcome the limitation of morphological classification, there is a need to carry out genetic characterization of the various durian types. Such data is important for the evaluation and management of durian genetic resources in producing countries. In this study, simple sequence repeat (SSR) markers were used to study the genetic variation in 27 durian types from the germplasm collection of Universiti Putra Malaysia. Based on DNA sequences deposited in Genbank, seven pairs of primers were successfully designed to amplify SSR regions in the durian DNA samples. High levels of variation among the 27 durian types were observed (expected heterozygosity, $H_{E}=0.35$ ). The DNA fingerprinting power of SSR markers revealed by the combined probability of identity (PI) of all loci was $2.3 \times 10^{-3}$. Unique DNA fingerprints were generated for 21 out of 27 durian types using five polymorphic SSR markers (the other two SSR markers were monomorphic). We further tested the utility of these markers by evaluating the clonal status of shared durian types from different germplasm collection sites, and found that some were not clones. The findings in this preliminary study not only shows the feasibility of using SSR markers for DNA fingerprinting of durian types, but also challenges the current classification of durian types, e.g. on whether the different types should be called "clones", "varieties", or "cultivars". Such matters have a direct impact on the regulation and management of durian genetic resource in the region. 
1 Genetic variation and DNA fingerprinting of durian types in Malaysia using simple sequence

2 repeat $(\mathrm{SSR})$ markers

3 Ging Yang Siew ${ }^{1}$, Wei Lun $\mathrm{Ng}^{1,2,3^{*}}$, Sheau Wei $\operatorname{Tan}^{1}$, Noorjahan Banu Alitheen ${ }^{2 *}$, Soon Guan

$4 \operatorname{Tan}^{2}$, Swee Keong Yeap ${ }^{1,4}$

6 Abstract

7 Durian (Durio zibethinus) is one of the most popular tropical fruits in Asia. To date, 126 durian

8 types have been registered with the Department of Agriculture in Malaysia based on phenotypic

9 characteristics. Classification based on morphology is convenient, easy, and fast but it suffers

10 from phenotypic plasticity as a direct result of environmental factors and age. To overcome the

11 limitation of morphological classification, there is a need to carry out genetic characterization of

12 the various durian types. Such data is important for the evaluation and management of durian

13 genetic resources in producing countries. In this study, simple sequence repeat (SSR) markers

14 were used to study the genetic variation in 27 durian types from the germplasm collection of

15 Universiti Putra Malaysia. Based on DNA sequences deposited in Genbank, seven pairs of

16 primers were successfully designed to amplify SSR regions in the durian DNA samples. High

17 levels of variation among the 27 durian types were observed (expected heterozygosity, $\mathrm{H}_{\mathrm{E}}=0.35$ ).

18 The DNA fingerprinting power of SSR markers revealed by the total probability of identity (PI)

19 of all loci was $2.3 \times 10^{-3}$. Unique DNA fingerprints were generated for 21 out of 27 durian types

\footnotetext{
${ }^{1}$ Institute of Bioscience, Universiti Putra Malaysia, Selangor, Malaysia.

${ }^{2}$ Department of Cell and Molecular Biology, Faculty of Biotechnology and Biomolecular Sciences, Universiti Putra Malaysia, Selangor, Malaysia.

${ }^{3}$ School of Life Sciences, Sun Yat-sen University, Guangzhou, China

${ }^{4}$ China-ASEAN College of Marine Sciences, Xiamen University Malaysia, Sepang, Selangor, Malaysia.

* Corresponding authors (Wei Lun Ng; ng.w185@gmail.com, Noorjahan Banu Alitheen; noorjahan@upm.edu.my)
} 
20 using five polymorphic SSR markers (the other two SSR markers were monomorphic). We

21 further tested the utility of these markers by evaluating the clonal status of shared durian types

22 from different germplasm collection sites, and found that some were not clones. The findings in

23 this preliminary study not only show the feasibility of using SSR markers for DNA

24 fingerprinting of durian types, but also challenges the current classification of durian types, e.g.

25 on whether the different types should be called "clones", "varieties", or "cultivars". Such matters

26 have a direct impact on the regulation and management of durian genetic resource in the region. 


\section{Introduction}

Durian (Durio zibethinus) belongs to the family Malvaceae and is distinctively characterized by its large fruit size, unique odor when ripe, large seeds covered with fleshy or leathery arils, as well as thorn-covered husk (Integrated Taxonomic Information System on-line database, 2017; Nyffeler \& Baum, 2001). It is diploid with a chromosome number of $n=28$ (Brown, 1997). A recent study that reported the draft genome of durian estimated its genome size to be approximately $738 \mathrm{Mb}$ (Teh et al., 2017). Owing to its self-incompatibility, durian is mainly outcrossing, with fruit bats serving as its main pollinator in nature (Bumrungsri et al., 2009). In the genus Durio, a total of 34 species are known ("The Plant List", 2013), and at least nine of them produce edible fruits (Idris, 2011). Of the nine species, D. zibethinus is the most common and is often cultivated in home gardens or orchards.

Popularly known as the "King of Fruits", durian is one of the most popular tropical fruits in Asia. Believed to have originated from Borneo (Morton, 1987; Tarmizi \& Abidin, 1991), durian is widely cultivated in countries located near the equator such as Malaysia, Indonesia, Thailand, Myanmar, the Philippines, Sri Lanka, India, Australia, and Papua New Guinea (Tarmizi \& Abidin, 1991), and is found wild or semi-wild in many countries around South and Southeast Asia (Morton, 1987). Two of the largest exporters of durian in the world are Malaysia and 6 Thailand (Siriphanich, 2011). Durian from Malaysia, for example, is exported to many countries

7 including Singapore, Indonesia, Hong Kong, and China, which are the top four importers in 2015. 48 The export value to these countries alone in 2015 totaled approximately USD 14.8 million (Department of Agriculture Malaysia, personal communication, April 2016). 
51 Durian is classified into different "clones" or "varieties" (or "cultivars"), based on phenotypic

52 characters of the fruit. While cultivated durian is mostly asexually propagated (Brown, 1997), so

53 far no study has evaluated the clonality of cultivated durian. For consistency, and to remain

54 neutral at this stage, we shall use the term "durian type" throughout this paper. In Malaysia, 126

55 durian types have been registered with the Department of Agriculture Malaysia, as of September

562017 (Department of Agriculture Malaysia, n.d.-b), based on fruit shape, thorn size, aroma of the

57 fruit, and seed shape (Department of Agriculture Malaysia, 2010). Morphological characters are

58 easy to observe, fast, and cheap but they suffer from phenotypic plasticity as a direct result of

59 environmental factors (e.g. climate, nutrient and moisture content, and soil type) and age, which

60 may contribute to morphological variation (Chambel et al., 2005). To overcome the limitation of

61 phenotypic plasticity, there is a need to carry out genetic characterization on the registered durian

62 types.

Recently, there have been studies on the genetic variation of durian types from important durian producing countries using DNA markers such as inter-simple sequence repeat (ISSR) (Siew et al., 2017; Vanijajiva, 2012) and random amplified polymorphic DNA (RAPD) (Vanijajiva, 2011; Ruwaida et al., 2009) markers. While the ease of application of these markers makes them attractive choices for studies on overall genetic variation and population genetic structure $(\mathrm{Ng} \&$ Tan, 2015), the dominant nature of these markers do not work well with applications such as DNA fingerprinting (Kirst et al., 2005). Moreover, the data generated from dominant genetic markers are not as informative as co-dominant markers and some are known to suffer from poor 
72 reproducibility (Semagn et al., 2006), throwing into question the feasibility and reliability of

73 using such markers for downstream applications. Simple sequence repeat (SSR) markers, on the

74 other hand, are codominant, multi-allelic, and highly reproducible. They are one of the most

75 powerful markers for plant variety identification and have been successfully applied to study

76 genetic variation in a wide range of cultivated plant species such as oil camellia (Camellia

77 oleifera; Chen et al., 2016), rice (Oryza sativa; Sarao et al, 2009), and jute (Corchorus spp.;

78 Zhang et al., 2015). The availability of markers that generate highly accurate and reproducible

79 results is important for the evaluation and subsequent management of genetic resources.

81 To our knowledge, few studies have used SSR markers to study the genetic variation in durian 82 (e.g. Sales, 2015; Santoso et al., 2017). In this study, SSR markers were designed from publicly available DNA sequences containing SSR regions, and used to study the genetic variation among major durian types found in Malaysia. We also evaluated the feasibility of using these markers to genetically fingerprint the various durian types. Finally, we determined the clonality of several durian types sampled from different collection sites, and discuss the implications of our findings toward the regulation and management of durian genetic resources in the region.

\section{Materials and Methods}

\section{Sampling and DNA extraction}

Leaves from a total of 45 durian trees were collected across five durian orchards (that also serve as germplasm collection sites) of Universiti Putra Malaysia, namely Bukit Ekspo (BE), Bukit 
93 Ekspo Plot A (BEA), Putra Mart (PM), Ladang Puchong (LP), and Ladang 5 (5L) (Table 1).

94 These durian trees have been pre-identified and pre-labeled for the types of durian fruit that they

95 produce. The experimental material consist of 27 samples that represent different durian types,

96 and 18 samples that represent replicates of some of the durian types (i.e. D2, D7, D8, D24, D99,

97 D159, D168, D188, and D197) from different orchards. Many of the sampled durian types in this

98 study are popular commercial types (e.g. D24, D160, D168, and D197; Department of 99 Agriculture Malaysia, personal communication, October 2017), and most have not been studied 100 for genetic diversity using SSR markers.

102 For DNA extraction, $100 \mathrm{mg}$ of fresh leaf material was ground to powder in liquid nitrogen. 103 Genomic DNA was extracted from the ground leaf material using the cetyl trimethylammonium 104 bromide (CTAB) extraction method as described by Doyle \& Doyle (1990). The crude DNA 105 extract was further purified using the GF-1 Plant DNA Extraction Kit (Vivantis Technologies 106 Sdn. Bhd., Malaysia) before further analyses. The purified DNA was quantified using a 107 Nanodrop spectrophotometer (Beckman Coulter, USA).

Selection of SSR primers and detection of PCR products

110 Eight pairs of SSR primers were designed from seven DNA sequences containing SSR regions 111 that were deposited in Genbank, using Primer-BLAST (Ye et al., 2012). Detailed primers 112 sequences and their sources are listed in Table 2. A $20 \mu \mathrm{L}$ PCR reaction mixture contains $1 \times$ 113 NEXpro ${ }^{\mathrm{TM}}$ e PCR Master Mix (Genes Laboratories, Korea), $0.2 \mu \mathrm{M}$ each of the forward and 114 reverse primers, and approximately $20 \mathrm{ng}$ of genomic DNA. The designed primers were initially 
115 tested on two durian DNA samples using two types of PCR protocols on a thermocycler. The

116 first PCR profile consists of an initial denaturation of $3 \mathrm{~min}$ at $95{ }^{\circ} \mathrm{C}$, followed by 30 cycles of

$11730 \mathrm{sec}$ at $95^{\circ} \mathrm{C}, 30 \mathrm{sec}$ at $55^{\circ} \mathrm{C}$ or $60{ }^{\circ} \mathrm{C}$, and $2 \mathrm{~min}$ at $72{ }^{\circ} \mathrm{C}$ followed by an extension step at 72

$118{ }^{\circ} \mathrm{C}$ for $7 \mathrm{~min}$; and the second PCR used a touch-down protocol that started with an initial 119 denaturation of $3 \mathrm{~min}$ at $95^{\circ} \mathrm{C}$, then 10 cycles of $30 \mathrm{sec}$ at $95{ }^{\circ} \mathrm{C}, 30 \mathrm{sec}$ at $60{ }^{\circ} \mathrm{C}\left(-1^{\circ} \mathrm{C} / \mathrm{cycle}\right)$, 120 and $1 \mathrm{~min}$ at $72{ }^{\circ} \mathrm{C}$, followed by 25 cycles of $30 \mathrm{sec}$ at $95{ }^{\circ} \mathrm{C}, 30 \mathrm{sec}$ at $50^{\circ} \mathrm{C}$, and $1 \mathrm{~min}$ at $72{ }^{\circ} \mathrm{C}$, 121 with a final extension step at $72{ }^{\circ} \mathrm{C}$ for $7 \mathrm{~min}$. Resultant PCR amplicons for each marker were 122 Sanger-sequenced on an ABI 3730 sequencer, through services provided by First Base 123 Laboratories Sdn Bhd. (Selangor, Malaysia), in order to verify that the amplicons were the 124 targeted regions that contained SSR sequences. Markers that worked well and the corresponding 125 PCR conditions were subsequently used to genotype all durian samples. PCR amplicons were 126 analyzed through electrophoresis on $8 \%(\mathrm{w} / \mathrm{v})$ polyacrylamide gels, stained with ethidium 127 bromide and viewed under UV illumination. The DNA fragment sizes were estimated by 128 comparison of sample banding patterns with a 50 bp DNA ladder (New England Biolabs Inc., 129 USA) loaded in the same gel. PCR and polyacrylamide gel electrophoresis were repeated to 130 ensure consistency of the results.

Data analysis

133 Genetic variability and fingerprinting

134 The estimation of genetic variability and fingerprinting power was conducted on the 27 durian 135 samples representing different durian types. The estimated DNA fragment sizes of each sample 136 at each locus were manually recorded. GenAlEx 6.502 (Peakall \& Smouse, 2012) was used to 
137 estimate basic genetic parameters, such as the total number of alleles, number of alleles per locus,

138 allele frequency, as well as the expected $\left(\mathrm{H}_{\mathrm{E}}\right)$ and observed $\left(\mathrm{H}_{\mathrm{O}}\right)$ heterozygosities.

139

140 The probability of identity (PI) of each marker and of the combination of all loci were calculated

141 using GenAlEx 6.502 (Peakall \& Smouse, 2012) to assess the fingerprinting power of the SSR

142 markers. The DNA fragments obtained from seven pairs of SSR primers were used for DNA

143 fingerprinting. The amplified fragments of SSRs were encoded 0 for absence of a band and 1 for

144 presence of a band for an allele using GenAlEx 6.502 (Peakall \& Smouse, 2012).

146 The same markers were also used to genotype 18 additional samples representing replicates of 147 some of the durian types (i.e. D2, D7, D8, D24, D99, D159, D168, D188, and D197) obtained 148 from different orchards. DNA fingerprints were generated as above and compared among 149 samples of the same durian type.

150

151 Results

152

153 SSR data analysis

154 Of the eight SSR primer pairs designed, seven primer pairs successfully amplified clear and 155 reproducible bands in all 27 durian types. Five loci were polymorphic and two loci were 156 monomorphic. A total of 19 alleles were scored across seven SSR loci, ranging from one to five 
157 alleles per locus with an average of 2.714 alleles per locus. The allele frequency of each allele at

158 each locus ranged from 0.074 to 1 . The $\mathrm{H}_{\mathrm{O}}$ ranged from 0 to 0.667 with a mean $\mathrm{H}_{\mathrm{O}}$ of 0.238 ,

159 while the $\mathrm{H}_{\mathrm{E}}$ ranged from 0 to 0.621 with a mean $\mathrm{H}_{\mathrm{E}}$ of 0.35 . The $\mathrm{H}_{\mathrm{E}}$ was generally higher than

$160 \mathrm{H}_{\mathrm{O}}$ at all loci except DZ04. Excluding monomorphic loci, the mean $\mathrm{H}_{\mathrm{O}}$ was 0.42 , while the mean

$161 \mathrm{H}_{\mathrm{E}}$ was 0.49 . Detailed results are presented in Table 3.

A total of 17 polymorphic bands were obtained from the seven SSR loci. The PI of each locus and the PI estimated using all loci (hereinafter, 'total PI') were calculated to assess the fingerprinting power of the markers (Table 3). For each locus, the PI value ranged from 0.2 to 1. Assuming that there was no linkage disequilibrium and all loci segregated independently, the chance of finding samples with identical fingerprints is equal to the total PI for all loci, which is $2.3 \times 10^{-3}$. When only one locus was involved, zero to four $(0-14.81 \%)$ durians types had distinct

170 fingerprint profiles; when two loci were included, zero to $13(0-48.15 \%)$ durian types had 171 distinct fingerprint profiles; when three loci were included, zero to $21(0-77.78 \%)$ durian types 172 were identified; when four loci were included, two to $21(7.41-77.78 \%)$ durian types were 173 identified; when five loci were included, nine to $21(33.33-77.78 \%)$ durian types were identified; 174 when six loci were included, 16 to $21(59.26-77.78 \%)$ durian types were identified; when all 175 seven loci were included, $21(77.78 \%)$ durian types were identified. The remaining six $(22.22 \%)$ 176 durian types did not have unique fingerprints: D2 shared the same fingerprint with D10, D7 177 shared the same fingerprint as D188, and D168 shared the same fingerprint as D197. The results 
178 implied that seven SSR markers have successfully fingerprinted 21 out of 27 durian types tested

179 in this study. Detailed results are presented in Tables 4 to 6.

Fingerprinting of durian types across orchards

182

183

184

185

186

187

188

\section{Discussion:}


199 As far as we are aware, this is one of few studies that have used SSR markers to evaluate genetic 200 variation in durian. A study by Santoso et al. (2017) reported the development of SSR markers

201 for the study of genetic variation in durian. However, none of the 11 markers reported contained

202 perfect repeat motifs. Homoplasy has been found to be common with imperfect repeats, i.e.

203 compound and/or interrupted repeats (Adams et al., 2004), which biases the estimation of genetic

204 variation (Selkoe \& Toonen, 2006) and renders those markers unsuitable for DNA fingerprinting.

Sales (2015) reported the evaluation of 127 sets of SSR primers on 187 durian types. In the current study, we synthesized and pretested the 29 primer pairs recommended in Sales, (2015) on our durian DNA samples, but none of the primers amplified specific fragments containing SSRs. The primers used in the study were initially developed for cotton (Gossypium spp.), explaining the poor transferability of the primers to durian. SSR markers have been known to be transferable across species within a genus (Gonçalves-Vidigal \& Rubiano, 2011; Hodel et al., 2016; Selkoe \& Toonen, 2006), but cases of transferability across higher taxonomic levels are 213 rare.

$\mathrm{H}_{\mathrm{E}}$ is one of the most important and commonly used estimators of genetic diversity when using

217 codominant markers such as SSR markers (Bashalkhanov et al., 2009; Nybom, 2004). A high

218 level of genetic diversity among durian types was observed in this study, partly due to the 219 outbreeding nature of the species (Asrul \& Sarip, 2009). A high level of genetic diversity of the 220 durian types found in our study was comparable to that of some cultivated fruit plants such as 
221 coconut (Cocos nucifera, mean $\mathrm{H}_{\mathrm{E}}=0.377$; Liu et al., 2011), but lower than that found in other

222 wild fruit species such as wild banana (Musa balbisiana, mean $\mathrm{H}_{\mathrm{E}}=0.817$; Ravishankar et al.,

223 2013). This is reasonable as only certain durian types are preferentially grown. The genetic

224 diversity estimates could also be affected by sample sizes and numbers of loci used in different

225 studies and sample size is one of the most important factors affecting genetic diversity within

226 population (Bashalkhanov et al., 2009) as it directly affects the number of scored alleles which is

227 used to measure $\mathrm{H}_{\mathrm{E}}$. Furthermore, the loci chosen for a study might have a negative impact on

228 the mean $\mathrm{H}_{\mathrm{E}}$ if the loci were monomorphic (Nybom, 2004). This could be clearly observed in

229 this study as there were two monomorphic loci. If the two monomorphic loci were excluded, the

230 mean $\mathrm{H}_{\mathrm{E}}$ in this study increased from 0.35 to 0.49 in this study.

DNA fingerprinting power is calculated via the total PI of all loci. The lower the total PI value,

234 the higher the DNA fingerprinting power and the higher the probability of getting unique DNA

235 fingerprint profiles (Tan et al., 2015). The obtained total PI $=2.3 \times 10^{-3}$ in this study is considered

236 low (Waits 2001), and hence the markers can be thought as effective for DNA fingerprinting.

237 SSR markers used in Chinese tea cultivars showed a low total PI value of $4.8 \times 10^{-33}$ derived from

238312 alleles at 30 loci analyzed on 128 samples (Tan et al., 2015), and SSR markers used in

239 Tunisian almond (Prunus dulcis) showed a total PI value of $4 \times 10^{-13}$ derived from 159 alleles at

24010 loci that were on 82 samples (Gouta et al., 2010). 
242 Several factors can influence the ability to construct unique DNA fingerprint profiles, including

243 the number of polymorphic markers and sample size used. Depending on the level of

244 polymorphism of the markers used, the larger the sample size, the more the markers needed. In

245 this study, 21 out of 27 durian types were successfully fingerprinted with only five SSR loci,

246 demonstrating the effectiveness of these SSR markers for fingerprinting of durian types. Still,

247 comprehensive studies that include exhaustive sampling of all registered durian types for a

248 country or a region and more markers are necessary for evaluation of the feasibility of using

249 DNA fingerprinting in the management of registered durian types.

251 Like many other plants, durian can be either sexually (i.e. via seed) or asexually propagated.

252 Nevertheless, asexual propagation techniques such as cleft grafting, approach grafting, and

253 budding are more commonly practiced to propagate durians so that the quality and consistency of

254 the fruit are preserved (Abidin, 1991; Wiryanta, 2007). Six durian types (i.e. D2, D99, D197,

255 D159, D188, and D7) showed inconsistent DNA fingerprints across orchards, proving that they

256 are not clones, as clones should be identical in their genetic makeup. It is possible that

257 individuals with different genotypes still produced similar fruits, causing them to be categorized

258 as the same type. Such findings not only showed the utility and importance of DNA

259 fingerprinting in the identification of durian types, but also pose questions on the existing system

260 for the management of durian genetic resource in the region. 
263 DNA fingerprinting using SSR markers is very useful in assisting the determination of a newly

264 registered variety for Plant Variety Protection (PVP) application (Silva et al., 2012), and acting

265 as a tool to complement the assessment of morphological characters (Treuren et al., 2010). Apart

266 from using it in new plant variety registration, it can be used to evaluate currently registered

267 plant varieties to investigate if there are clones among registered types. This is particularly

268 important in PVP, as the owner of a new plant variety has the exclusive sale of the plant and

269 exploitation of the plant by the others is illegal. Such DNA fingerprinting method has been used

270 in fingerprinting some important economic crops such as olive cultivars in Turkey (Ercisli et al.,

271 2011), apple cultivars in the Netherlands (Treuren et al., 2010), and sugarcanes in Brazil (Silva et

272 al., 2012). Therefore, it is important to determine their identification at a genetic level to ensure

273 that the exported durians are true to a certain type.

275 The terms "clone" and "variety" are commonly used to refer to the different durian types (e.g.

276 Abidin, 1991; Department of Agriculture Malaysia, n.d.-a; Jawahir \& Kasiran, 2008), but each of

277 these terms has a different meaning and should not be used interchangeably. By definition, a

278 "clone" refers to an individual derived from another individual by asexual propagation ("What

279 are cultivars, clones and landraces", n.d.), and so cloned individuals are genetically identical to

280 another. A "variety" means a "plant grouping" that has a set of common characteristics within a

281 species. The term "variety" is not used to refer to a single plant, a trait, or a plant breeding

282 technology (International Union For The Protection of New Varieties of Plants, 2010). Therefore,

283 there is a need to reconsider the classification of the durian types we have today, especially by

284 the authority. Whether a registered type should be called a "clone" or a "variety" is not a matter

285 of preference; it affects other aspects related to the adoption of such classification, e.g. the 
286 legality revolving the rights to a registered type. If the current situation remains, it is likely that

287 the various durian types are different "varieties" or "cultivars", which are plants with a common

288 set of characteristics, rather than "clones". Then again, this poses a whole new challenge to

289 register, preserve, and validate the authenticity of the various types of durian in the market.

290

291 Conclusion:

292 Our results indicated that the SSR marker is a powerful tool to assess the genetic variability in

293 durian. High levels of genetic diversity $\left(\mathrm{H}_{\mathrm{E}}=0.35\right)$ found in durian in this study provides a

294 foundation for management of genetic resources for the future development of strategies for

295 germplasm sampling and genetic improvement of durian. The results also demonstrated the

296 effectiveness of using SSR markers to genetically fingerprint durian, with 21 out of 27 durian

297 types being successfully fingerprinted using just five markers. The analysis of durian types

298 across orchards has also confirmed that some are not clones, although the samples were claimed

299 to be of the same durian type, challenging the current classification method of durian types in the 300 region.

301

302

\section{Acknowledgement:}

303

304

305

306

We would like to thank the University Agricultural Park of Universiti Putra Malaysia for allowing us to access the orchards to collect the durian leaf samples.

\section{References:}


307 308

Abidin, Z. M. (1991). Klon-Klon durian. In Z. M. Abidin, S. A. Tarmizi, \& O. Azizar (Eds.), Penanaman Durian (pp. 12-17). KL: MARDI.

Adams, R. I., Brown, K. M., \& Hamilton, M. B. (2004). The impact of microsatellite electromorph size homoplasy on multilocus population structure estimates in a tropical tree (Corythophora alta) and an anadromous fish (Morone saxatilis). Mol. Ecol., 13(9), 2579-

Asrul, S. M., \& Sarip, J. (2009). Preliminary compatibility study of selected durian clones. Proceedings of the 8th Malaysia Congress on Genetics, 4-6.

Bashalkhanov, S., Pandey, M., \& Rajora, O. P. (2009). A simple method for estimating genetic diversity in large populations from finite sample sizes. BMC Genetics, 10, 84 .

Brown, M. J. (1997). Durio - a bibliographic review. IPGRI Office for South Asia, New Delhi.

Bumrungsri, S., Sripaoraya, E., Chongsiri, T., Sridith, K., \& Racey, P. A. (2009). The pollination ecology of durian (Durio zibethinus, Bombacaceae) in southern Thailand. J. Trop. Ecol., 25(1), 85-92.

Chambel, M. R., Climent, J., Alía, R., \& Valladares, F. (2005). Phenotypic plasticity: a useful framework for understanding adaptation in forest species. Invest. Agrar: Sist. Recur. For., 14(3), 334-344.

Chen, Y., Dai, X., Hou, J., Guan, H., Wang, Y., Li, Y., \& Yin, T. (2016). DNA fingerprinting of oil camellia cultivars with SSR markers. Tree Genet. Genomes, 12(1), 1-8.

Department of Agriculture Malaysia. (n.d.-a). Recommended plant varieties in Malaysia. Retrieved September 19, 2017, from http://pvpbkkt.doa.gov.my/Pengesyoran/Syor.php 
328 Department of Agriculture Malaysia. (n.d.-b). Varieties registered for national crop list.

329 Retrieved September 19, 2017, from http://pvpbkkt.doa.gov.my/NationalList/Search.php

330

331

332

333

334

335

336

337

338

339

340

341

342

343

344

345

346

347

Department of Agriculture Malaysia. (2010). Guidelines for the conduct of tests for distincness, uniformity and stability. Retrieved September 13, 2016, from http://pvpbkkt.doa.gov.my/TG/Fruits/Durian.doc

Doyle, J. J., \& Doyle, J. L. (1990). Isolation of plant DNA from fresh tissue. Focus, 12, 13-15.

Ercisli, S., Ipek, A., \& Barut, E. (2011). SSR marker-based DNA fingerprinting and cultivar identification of olives (Olea europaea). Biochem. Genet., 49, 555-561.

Gonçalves-Vidigal, M. C., \& Rubiano, L. B. (2011). Development and application of microsatellites in plant breeding. Crop Breed. Appl. Biotechnol., 11(spe), 66-72.

Gouta, H., Ksia, E., Buhner, T., Moreno, M. Á., Zarrouk, M., Mliki, A., \& Gogorcena, Y. (2010). Assessment of genetic diversity and relatedness among Tunisian almond germplasm using SSR markers. Hereditas, 147(6), 283-292.

Hodel, R. G. J., Segovia-Salcedo, M. C., Landis, J. B., Crowl, A. A., Sun, M., Liu, X., ... Soltis, P. S. (2016). The report of my death was an exaggeration: A review for researchers using microsatellites in the 21st Century. Appl. Plant Sci., 4(6), 1-13.

Idris, S. (2011). Introduction. In Durio of Malaysia (pp. 1-3). KL: MARDI.

Integrated Taxonomic Information System on-line database. (2017). ITIS report. Retrieved June 2, 2017, from http://www.itis.gov

International Union For The Protection of New Varieties of Plants. (2010). Explanatory notes on 
the definition of variety under the 1991 act of the UPOV convention. Retrieved April 12, 2016, from http://www.upov.int/edocs/expndocs/en/upov_exn_var.pdf

350

351

Jawahir, Z., \& Kasiran, Z. M. (2008). Klon durian. In Klon durian terpilih Malaysia (p. 2). Serdang, Selangor: UPM.

Kirst, M., Cordeiro, C. M., Rezende, G. D. S. P., \& Grattapaglia, D. (2005). Power of microsatellite markers for fingerprinting and parentage analysis in Eucalyptus grandis breeding populations. J. Hered., 96(2), 161-166.

Liu, X., Tang, H., Li, D., \& Hou, L. (2011). Genetic Diversity of Coconut Cultivars in China by Microsatellite (SSR) Markers. Mol. Plant Breed., 2(12), 83-91. Retrieved from http://biopublisher.ca/index.php/mpb/article/view/164

Morton, J. F. (1987). Durian. In Fruits of warm climates (pp. 287-291). Miami, FL: Julia F. Morton.

Ng, W. L., \& Tan, S. G. (2015). Inter-simple sequence repeat (ISSR) markers: are we doing it right? ASM Sci. J., 9(1), 48-57.

Nybom, H. (2004). Comparison of different nuclear DNA markers for estimating intraspecific genetic diversity in plants. Mol. Ecol., 13(5), 1143-1155.

Nyffeler, R., \& Baum, D. A. (2001). Systematics and character evolution in Durio s. lat. (Malvaceae/Helicteroideae/Durioneae or Bombacaceae-Durioneae). Org. Divers. \& Evol., 1(3), 165-178.

Peakall, R., \& Smouse, P. E. (2012). GenAlEx 6.5: genetic analysis in excel. population genetic software for teaching and research - an update. Bioinformatics, 28(19), 2537-2539. 
369 Ravishankar, K. V., Raghavendra, K. P., Athani, V., Rekha, A., Sudeepa, K., Bhavya, D.,

370 Srinivas, V., \& Ananad, L. (2013). Development and characterisation of microsatellite

371 markers for wild banana (Musa balbisiana). J. Hortic. Sci. Biotechnol., 88(5), 605-609.

372 Ruwaida, I. P., Supriyadi, \& Parjanto. (2009). Variability analysis of Sukun durian plant (Durio

373 zibethinus) based on RAPD marker. Nusantara Bioscie., 1(2), 84-91.

374 Sales, E. K. (2015). Durian marker kit for durian (Durio zibethinus Murr.) identity. Int. J. Biol., 375 Biomol., Agr., Food Biotechnol.Eng., 9(5), 518-528.

376 Santoso, P. J., Pancoro, A., Suhandono, S., \& Aryantha, I. N. P. (2017). Development of Simple-

377 Sequence Repeats Markers from Durian (Durio zibethinus Murr.cultv.Matahari) Genomic $378 \quad$ Library. $A J A S, 39(3), 257-265$.

379

Sarao, N. K., Vikal, Y., Singh, K., Joshi, M. A., \& Sharma, R. C. (2009). SSR marker-based DNA fingerprinting and cultivar identification of rice (Oryza sativa L.) in Punjab state of India. Plant Genet. Resour-C, 8(1), 42-44.

Selkoe, K. A., \& Toonen, R. J. (2006). Microsatellites for ecologists: a practical guide to using and evaluating microsatellite markers. Ecol. Lett., 9(5), 615-629.

Semagn, K., Bjørnstad, Å., \& Ndjiondjop, M. N. (2006). An overview of molecular marker methods for plants. Afr. J. Biotechnol., 5(25), 2540-2568.

Siew, G. Y., Ng, W. L., Salleh, M. F., Tan, S. W., Ky, H., Alitheen, N. B. M., Tan, S. G. \& Yeap, S. K. (2017). Assessment of the Genetic Variation of Malaysian Durian Varieties using Inter-simple Sequence Repeat Markers and Chloroplast DNA Sequences. JTAS, 40(4).

Silva, D. C., Sérgio, L., Duarte, C., \& Messias, J. (2012). DNA fingerprinting based on simple 
390

391

392

393

394

395

396

397

398

399

400

401

402

403

404

405

406

407

408

409

410

sequence repeat (SSR) markers in sugarcane clones from the breeding program RIDESA. Afr. J. Biotechnol., 11(21), 4722-4728.

Siriphanich, J. (2011). Durian (Durio zibethinus Merr.). In Postharvest biology and technology of tropical and subtropical fruits (pp. 80-116). Woodhead Publishing Limited.

Tan, L. Q., Peng, M., Xu, L. Y., Wang, L. Y., Chen, S. X., Zou, Y., Qi, G. N., \& Cheng, H. (2015). Fingerprinting 128 Chinese clonal tea cultivars using SSR markers provides new insights into their pedigree relationships. Tree Genet. Genomes, 11(5), 1-12.

Tarmizi, S. A., \& Abidin, M. Z. (1991). Pengenalan. In Z. M. Abidin, S. A. Tarmizi, \& O. Azizar (Eds.), Penanaman Durian (p. 9). KL: MARDI.

The Plant List. (2013). Retrieved May 2, 2016, from http://www.theplantlist.org/tpl1.1/search?q=durio

Treuren, R. Van, Kemp, H., Ernsting, G., Jongejans, B., Houtman, H., \& Visser, L. (2010). Microsatellite genotyping of apple (Malus $\times$ domestica Borkh.) genetic resources in the Netherlands: application in collection management and variety identification. Genet Resour. Crop Evol, 57(6), 853-865.

Vanijajiva, O. (2011). Genetic variability among durian (Durio zibethinus Murr.) cultivars in the Nonthaburi province, Thailand detected by RAPD analysis. J. Agric. Technol., 7(4), 11071116.

Vanijajiva, O. (2012). The application of ISSR markers in genetic variance detection among Durian (Durio zibethinus Murr.) cultivars in the Nonthaburi province, Thailand. Procedia Eng., 32, 155-159. 
411 Waits, L. P., Taberlet, P., \& Luikart, G. (2001). Estimating the probability of identity among

412 genotypes in natural populations: cautions and guidelines. Mol. Ecol., 10(1), 249-256.

413 What are cultivars, clones and landraces. (n.d.). Retrieved October 9, 2016, from

414 http://b4fa.org/bioscience-in-brief/plantbreeding/cultivars-clones-landraces/

415 Wiryanta, B. T. W. (2007). Pembiakan durian. In A. H. Idrus (Ed.), Penanaman Durian (pp. 28416 36). KL: Synergy Media Books.

417 Ye, J., Coulouris, G., Zaretskaya, I., Cutcutache, I., Rozen, S., \& Madden, T. L. (2012). Primer418 BLAST: A tool to design target-specific primers for polymerase chain reaction. BMC 419 Bioinformatics, 13(1), 134.

420 Zhang, L., Cai, R., Yuan, M., Tao, A., Xu, J., Lin, L., Fang, P., \& Qi, J. (2015). Genetic diversity 421 and DNA fingerprinting in jute (Corchorus spp.) based on SSR markers. Crop J., 3(5), 416$422 \quad 422$. 


\section{Table 1 (on next page)}

Details of durian samples used in this study 
1 Table 1. Details of durian samples used in this study

\begin{tabular}{|c|c|c|c|c|}
\hline No. & Type & Common Name & $\begin{array}{l}\text { No. of samples } \\
\left(\text { sampling location }{ }^{a}\right)\end{array}$ & Place of Origin \\
\hline 1 & D2 & Dato' Nina & 4 (PM, LP, BE, BEA) & Melaka \\
\hline 2 & D7 & $\mathrm{N} / \mathrm{A}$ & 4 (LP, 5L, BE, BEA) & Selangor \\
\hline 3 & D8 & $\mathrm{N} / \mathrm{A}$ & $1(\mathrm{LP})$ & Kuala Lumpur \\
\hline 4 & D10 & Durian Hijau & $1(\mathrm{PM})$ & Selangor \\
\hline 5 & D16 & $\mathrm{N} / \mathrm{A}$ & 1 (BEA) & $\mathrm{N} / \mathrm{A}$ \\
\hline 6 & D24 & N/A & $\begin{array}{l}5 \text { (PM, LP, 5L, BE, } \\
\text { BEA) }\end{array}$ & Perak \\
\hline 7 & D84 & N/A & $1(5 \mathrm{~L})$ & Perak \\
\hline 8 & D88 & Bangkok 8 & $1(5 \mathrm{~L})$ & Selangor \\
\hline 9 & D96 & Bangkok A & $3(\mathrm{PM}, \mathrm{LP}, 5 \mathrm{~L})$ & Selangor \\
\hline 10 & D99 & Kop Kecil & $3(\mathrm{PM}, \mathrm{LP}, 5 \mathrm{~L})$ & Thailand \\
\hline 11 & D125 & Kop Jantung & $1(5 \mathrm{~L})$ & Kedah \\
\hline 12 & D145 & Tuan Mek Hijau/Beserah & $1(\mathrm{LP})$ & Pahang \\
\hline 13 & D148 & Paduka & $1(\mathrm{LP})$ & Perak \\
\hline 14 & D158 & Kan Yau/Tangkai Panjang & $1(\mathrm{LP})$ & Kedah \\
\hline 15 & D159 & Mon Thong/Bantal Mas & $1(\mathrm{LP})$ & Kedah \\
\hline 16 & D160 & Buluh Bawah & $1(\mathrm{LP})$ & Selangor \\
\hline 17 & D162 & Tawa & $1(\mathrm{LP})$ & Selangor \\
\hline 18 & D168 & Durian Mas Hjh. Hasmah & $3(\mathrm{PM}, \mathrm{LP}, 5 \mathrm{~L})$ & Johor \\
\hline 19 & D169 & Tok LiTok & $1(\mathrm{LP})$ & Kelantan \\
\hline 20 & D172 & Durian Botak & $1(\mathrm{LP})$ & Johor \\
\hline 21 & D175 & Udang Merah & $1(\mathrm{LP})$ & Pulau Pinang \\
\hline 22 & D188 & MDUR 78 & $2(\mathrm{LP}, \mathrm{BE})$ & Terengganu \\
\hline 23 & D189 & MDUR 79 & $1(\mathrm{LP})$ & Terengganu \\
\hline 24 & D190 & MDUR 88 & $1(\mathrm{PM})$ & Terengganu \\
\hline 25 & D197 & Raja Kunyit/Musang King & 2 (PM, LP) & Kelantan \\
\hline 26 & Durian Gergasi (DG) & $\mathrm{N} / \mathrm{A}$ & $1(\mathrm{LP})$ & $\mathrm{N} / \mathrm{A}$ \\
\hline 27 & Durian Siam (DS) & $\mathrm{N} / \mathrm{A}$ & 1 (BEA) & $\mathrm{N} / \mathrm{A}$ \\
\hline
\end{tabular}

2 Note: Information of the common name and the place of origin are based on the records of 3 Department of Agriculture (Department of Agriculture Malaysia, n.d.-b); N/A=Not available; ${ }^{a}$ $4 \mathrm{PM}=$ Putra Mart, LP=Ladang Puchong, BE=Bukit Ekspo, BEA=Bukit Ekspo Plot A, 5L=Ladang 55. 
Table 2 (on next page)

SSR primers used in this study 
1 Table 2. SSR primers used in this study

\begin{tabular}{lllcc}
\hline Locus & $\begin{array}{l}\text { Primer } \\
\text { name }\end{array}$ & Primer sequence $\left(5^{\prime} \rightarrow 3^{\prime}\right)$ & $\begin{array}{l}\text { Accession number } \\
\text { of source sequence } \\
\text { on Genbank }\end{array}$ & $\begin{array}{l}\text { Successful } \\
\text { amplification } \\
\text { of intended } \\
\text { fragment? }\end{array}$ \\
\hline DZ01 & DZ01_F2 & AATTCCACATGACAGACAGG & AB292171 & Yes \\
& DZ01_R & TCATGGATGTTGTATGGCAG & AB292166 & Yes \\
\hline DZ02 & DZ02_F & ACCTTCTCCCCATTTCACC & & Yes \\
& DZ02_R & TGTTGAAGTCATACGTTTAGCC & AB292168 & Yes \\
\hline DZ03 & DZ03_F & CTCTAAAAAGAATGGGGATATTG & AB292170 & Yes \\
& DZ03_R & ATTCTGGAACAAAAGTTACAAAC & AB292169 & No \\
\hline DZ04 & DZ04_F2 & TGCATGTTTTGAAAAGTACC & & \\
& DZ04_R2 & ATGGGGAAAAGAAAGTGAAG & AB292165 & \\
\hline DZ05 & DZ05_F2 & ACACATACACAACTCACCTC & & Yes \\
& DZ05_R & ATGCCCGATGAAATTGTAAC & & Yes \\
\hline DZ06 & DZ06_F & ATGGGATTTGGATGATGGGTTG & & \\
& DZ06_R & CGACTCACTATAGGGCGAATTG & & \\
& DZ06_F2 & AGGTTGAATTGAACTGGGTTTTG & & \\
& DZ06_R2 & GCGGGAATTCGATTGATGAG & & \\
\hline DZ07 & DZ07_F & ACACACCATCTTCCCTTTG & & \\
& DZ07_R & TGCACATGTTGTTTGTATATATG & & AB292167 \\
\hline DZ08 & DZ08_F & ACATATATACAAACAACATGTGC & & \\
& DZ08_R2 & GTCCAATGATGGAAAAACTC & & \\
\hline
\end{tabular}




\section{Table 3 (on next page)}

Genetic variability and fingerprinting power of the seven SSR markers used in this study 
Table 3. Genetic variability and fingerprinting power of the seven SSR markers used in this study.

\begin{tabular}{|c|c|c|c|c|c|c|}
\hline Locus & $\begin{array}{l}\text { Number } \\
\text { of alleles }\end{array}$ & Allele & $\begin{array}{c}\text { Allele } \\
\text { frequency }\end{array}$ & $\mathrm{H}_{\mathrm{E}}$ & $\mathrm{H}_{\mathrm{O}}$ & PI \\
\hline \multirow{4}{*}{ DZ01 } & \multirow{4}{*}{4} & 210 & 0.074 & \multirow{4}{*}{0.615} & \multirow{4}{*}{0.519} & \multirow{4}{*}{0.2} \\
\hline & & 226 & 0.222 & & & \\
\hline & & 250 & 0.148 & & & \\
\hline & & 260 & 0.556 & & & \\
\hline \multirow{5}{*}{ DZ02 } & \multirow{5}{*}{5} & 320 & 0.019 & \multirow{5}{*}{0.501} & \multirow{5}{*}{0.259} & \multirow{5}{*}{0.28} \\
\hline & & 340 & 0.093 & & & \\
\hline & & 350 & 0.685 & & & \\
\hline & & 360 & 0.111 & & & \\
\hline & & 376 & 0.093 & & & \\
\hline \multirow{3}{*}{ DZ03 } & \multirow{3}{*}{3} & 126 & 0.167 & \multirow{3}{*}{0.575} & \multirow{3}{*}{0.222} & \multirow{3}{*}{0.25} \\
\hline & & 140 & 0.574 & & & \\
\hline & & 150 & 0.259 & & & \\
\hline \multirow{3}{*}{ DZ04 } & \multirow{3}{*}{3} & 200 & 0.37 & \multirow{3}{*}{0.621} & \multirow{3}{*}{0.667} & \multirow{3}{*}{0.22} \\
\hline & & 210 & 0.167 & & & \\
\hline & & 226 & 0.463 & & & \\
\hline DZ05 & 1 & 200 & 1 & 0 & 0 & 1 \\
\hline DZ07 & 1 & 440 & 1 & 0 & 0 & 1 \\
\hline \multirow{2}{*}{ DZ08 } & \multirow{2}{*}{2} & 140 & 0.926 & \multirow{2}{*}{0.137} & \multirow{2}{*}{0} & \multirow{2}{*}{0.75} \\
\hline & & 160 & 0.074 & & & \\
\hline $\begin{array}{c}\text { Mean } \\
\text { (excluding } \\
\text { monomorphic } \\
\text { loci) }\end{array}$ & 2.714 & - & - & $0.35(0.49)$ & $0.238(0.42)$ & - \\
\hline Combined & - & - & - & - & - & $2.3 \times 10^{-3}$ \\
\hline
\end{tabular}




\section{Table 4(on next page)}

Number of durian types differentiated based on different marker combinations 
1 Table 4. Number of durian types differentiated based on different marker combinations

\begin{tabular}{lc}
\hline Marker combinations & No. durian type \\
\hline One marker & 0 \\
\hline DZ01 & 4 \\
\hline DZ02 & 2 \\
\hline DZ03 & 0 \\
\hline DZ04 & 0 \\
\hline DZ05 & 0 \\
\hline DZ07 & 0 \\
\hline DZ08
\end{tabular}

\begin{tabular}{lc}
\hline Two markers & \\
\hline DZ01, DZ02 & 13 \\
\hline DZ01, DZ03 & 10 \\
\hline DZ01, DZ04 & 9 \\
\hline DZ01, DZ05 & 0 \\
\hline DZ01, DZ07 & 0 \\
\hline DZ01, DZ08 & 2 \\
\hline DZ02, DZ03 & 12 \\
\hline DZ02, DZ04 & 11 \\
\hline DZ02, DZ05 & 4 \\
\hline DZ02, DZ07 & 4 \\
\hline DZ02, DZ08 & 6 \\
\hline DZ03, DZ04 & 7 \\
\hline DZ03, DZ05 & 2 \\
\hline DZ03, DZ07 & 2 \\
\hline DZ03, DZ08 & 2 \\
\hline DZ04, DZ05 & 0 \\
\hline DZ04, DZ07 & 0 \\
\hline DZ04, DZ08 & 2 \\
\hline DZ05, DZ07 & 0 \\
\hline DZ05, DZ08 & 0 \\
\hline DZ07, DZ08 & 0 \\
\hline
\end{tabular}

\begin{tabular}{ll}
\hline Three markers & \\
\hline DZ01, DZ02, DZ03 & 19 \\
\hline DZ01, DZ02, DZ04 & 17 \\
\hline DZ01, DZ02, DZ05 & 13 \\
\hline DZ01, DZ02, DZ07 & 13 \\
\hline DZ01, DZ02, DZ08 & 13 \\
\hline DZ01, DZ03, DZ04 & 21 \\
\hline DZ01, DZ03, DZ05 & 10 \\
\hline DZ01, DZ03, DZ07 & 10 \\
\hline DZ01, DZ03, DZ08 & 12 \\
\hline
\end{tabular}




\begin{tabular}{|c|c|}
\hline DZ01, DZ04, DZ05 & 9 \\
\hline DZ01, DZ04, DZ07 & 9 \\
\hline DZ01, DZ04, DZ08 & 11 \\
\hline DZ01, DZ05, DZ07 & 0 \\
\hline DZ01, DZ05, DZ08 & 2 \\
\hline DZ01, DZ07, DZ08 & 2 \\
\hline DZ02, DZ03, DZ04 & 16 \\
\hline DZ02, DZ03, DZ05 & 12 \\
\hline DZ02, DZ03, DZ07 & 12 \\
\hline DZ02, DZ03, DZ08 & 14 \\
\hline DZ02, DZ04, DZ05 & 11 \\
\hline DZ02, DZ04, DZ07 & 11 \\
\hline DZ02, DZ04, DZ08 & 11 \\
\hline DZ02, DZ05, DZ07 & 4 \\
\hline DZ02, DZ05, DZ08 & 14 \\
\hline DZ03, DZ04, DZ05 & 7 \\
\hline DZ03, DZ04, DZ07 & 7 \\
\hline DZ03, DZ04, DZ08 & 9 \\
\hline DZ04, DZ05, DZ07 & 0 \\
\hline DZ04, DZ07, DZ08 & 2 \\
\hline DZ05, DZ07, DZ08 & 0 \\
\hline \multicolumn{2}{|l|}{ Four markers } \\
\hline DZ01, DZ02, DZ03, DZ04 & 21 \\
\hline $\mathrm{DZ} 01, \mathrm{DZ} 02, \mathrm{DZ} 03, \mathrm{DZ} 05$ & 19 \\
\hline 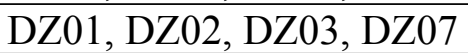 & 19 \\
\hline $\mathrm{DZ01,} \mathrm{DZ02,} \mathrm{DZ} 03, \mathrm{DZ} 08$ & 19 \\
\hline DZ01, DZ02, DZ04, DZ05 & 17 \\
\hline DZ01, DZ02, DZ04, DZ07 & 17 \\
\hline $\mathrm{DZ01,DZ02,} \mathrm{DZ04,} \mathrm{DZ08}$ & 17 \\
\hline $\mathrm{DZ} 01, \mathrm{DZ} 02, \mathrm{DZ} 05, \mathrm{DZ} 07$ & 13 \\
\hline DZ01, DZ02, DZ05, DZ08 & 13 \\
\hline DZ01, DZ02, DZ07. DZ08 & 13 \\
\hline $\mathrm{DZ01,DZ03,DZ04,DZ05}$ & 21 \\
\hline DZ01, DZ03, DZ04, DZ07 & 21 \\
\hline DZ01, DZ03, DZ04, DZ08 & 21 \\
\hline DZ01, DZ03, DZ05, DZ07 & 21 \\
\hline $\mathrm{DZ01,DZ03,} \mathrm{DZ05,} \mathrm{DZ08}$ & 21 \\
\hline DZ01, DZ03, DZ07, DZ08 & 21 \\
\hline DZ01, DZ04, DZ05, DZ07 & 9 \\
\hline DZ01, DZ04, DZ05, DZ08 & 11 \\
\hline $\mathrm{DZ01,DZ05,} \mathrm{DZ07,} \mathrm{DZ08}$ & 3 \\
\hline $\mathrm{DZ} 02, \mathrm{DZ} 03, \mathrm{DZ} 04, \mathrm{DZ} 05$ & 16 \\
\hline $\mathrm{DZ02,DZ03,DZ04,} \mathrm{DZ07}$ & 16 \\
\hline $\mathrm{DZ} 02, \mathrm{DZ} 03, \mathrm{DZ} 04, \mathrm{DZ} 08$ & 16 \\
\hline
\end{tabular}




\begin{tabular}{lc}
\hline DZ02, DZ03, DZ05, DZ07 & 12 \\
\hline DZ02, DZ03, DZ05, DZ08 & 14 \\
\hline DZ02, DZ03, DZ07, DZ08 & 14 \\
\hline DZ02, DZ04, DZ05, DZ07 & 11 \\
\hline DZ02, DZ04, DZ05, DZ08 & 11 \\
\hline DZ02, DZ04, DZ07, DZ08 & 11 \\
\hline DZ03, DZ04, DZ05, DZ07 & 11 \\
\hline DZ03, DZ04, DZ05, DZ08 & 2 \\
\hline DZ04, DZ05, DZ07, DZ08 & \\
\hline & 21 \\
\hline Five markers & 21 \\
\hline DZ01, DZ02, DZ03, DZ04, DZ05 & 21 \\
\hline DZ01, DZ02, DZ03, DZ04, DZ07 & 19 \\
\hline DZ01, DZ02, DZ03, DZ04, DZ08 & 19 \\
\hline DZ01, DZ02, DZ03, DZ05, DZ07 & 19 \\
\hline DZ01, DZ02, DZ03, DZ05, DZ08 & 17 \\
\hline DZ01, DZ02, DZ03, DZ07, DZ08 & 17 \\
\hline DZ01, DZ02, DZ04, DZ05, DZ07 & 21 \\
\hline DZ01, DZ02, DZ04, DZ05, DZ08 & 21 \\
\hline DZ01, DZ03, DZ04, DZ05, DZ07 & 21 \\
\hline DZ01, DZ03, DZ04, DZ05, DZ08 & 12 \\
\hline DZ01, DZ03, DZ04, DZ07, DZ08 & 11 \\
\hline DZ01, DZ03, DZ05, DZ07, DZ08 & 16 \\
\hline DZ01, DZ04, DZ05, DZ07, DZ08 & 16 \\
\hline DZ02, DZ03, DZ04, DZ05, DZ07 & 16 \\
\hline DZ02, DZ03, DZ04, DZ05, DZ08 & 11 \\
\hline DZ02, DZ03, DZ04, DZ07, DZ08 & 11 \\
\hline DZ02, DZ03, DZ05, DZ07, DZ08 & 17 \\
\hline DZ02, DZ04, DZ05, DZ07, DZ08 & 21 \\
\hline DZ03, DZ04, DZ05, DZ07, DZ08 & 16 \\
\hline & \\
\hline Six markers & \\
\hline DZ01, DZ02, DZ03, DZ04, DZ05, DZ07 & \\
\hline DZ01, DZ02, DZ03, DZ04, DZ05, DZ08 & \\
\hline DZ01, DZ02, DZ03, DZ05, DZ07, DZ08 & \\
\hline DZ01, DZ02, DZ04, DZ05, DZ07, DZ08 & \\
\hline DZ01, DZ03, DZ04, DZ05, DZ07, DZ08 & \\
\hline DZ02, DZ03, DZ04, DZ05, DZ07, DZ08 & \\
\hline SZven markers & \\
\hline
\end{tabular}


Table 5 (on next page)

DNA fingerprint profiles of 27 durian types in fragment sizes 
1 Table 5. DNA fingerprint profiles of 27 durian types in fragment sizes

\begin{tabular}{ccc}
\hline Durian type & DNA fingerprint profile & Shared / Unique \\
\hline D2 & 260260350350140140200210200200440440140140 & Shared (with D10) \\
\hline D7 & 210260350350150150200226200200440440140140 & Shared (with D188) \\
\hline D8 & 226226350350150150200226200200440440140140 & Unique \\
\hline D10 & 260260350350140140200210200200440440140140 & Shared (with D2) \\
\hline D16 & 260260350350140140200200200200440440140140 & Unique \\
\hline D24 & 250260320360140140210226200200440440140140 & Unique \\
\hline D84 & 260260350376150150226226200200440440160160 & Unique \\
\hline D88 & 226260350350126126200226200200440440140140 & Unique \\
\hline D96 & 260260350350150150200210200200440440140140 & Unique \\
\hline D99 & 260260350350140140226226200200440440140140 & Unique \\
\hline D125 & 226260350350140140200226200200440440140140 & Unique \\
\hline D145 & 226260350376126126200200200200440440140140 & Unique \\
\hline D148 & 226250350360140150200200200200440440140140 & Unique \\
\hline D158 & 260260340360126140200226200200440440140140 & Unique \\
\hline D159 & 260260376376140140210226200200440440140140 & Unique \\
\hline D160 & 250260350376140140200226200200440440140140 & Unique \\
\hline D162 & 250250350350140140200200200200440440140140 & Unique \\
\hline D168 & 226260350350140140210226200200440440140140 & Shared (with D197) \\
\hline D169 & 226226360360140140200226200200440440140140 & Unique \\
\hline D172 & 226250340340126140210226200200440440160160 & Unique \\
\hline D175 & 250250340340126140226226200200440440140140 & Unique \\
\hline D188 & 210260350350150150200226200200440440140140 & Shared (with D7) \\
\hline D189 & 210260350360150150226226200200440440140140 & Unique \\
\hline D190 & 210260350350140140226226200200440440140140 & Unique \\
\hline D197 & 226260350350140140210226200200440440140140 & Shared (with D168) \\
\hline DG & 260260350350126150210226200200440440140140 & Unique \\
\hline DS & 226260350350126140200226200200440440140140 & Unique \\
\hline DG D &
\end{tabular}

2 Note: $\mathrm{DG}=$ Durian Gergasi; DS = Durian Siam 
Table 6(on next page)

DNA fingerprint profiles of 27 durian types in binary 
1 Table 6 DNA fingerprint profiles of 27 durian types in binary

\begin{tabular}{|c|c|c|}
\hline Durian type & DNA fingerprint profile & Unique/Shared \\
\hline $\mathrm{D} 2$ & 0001001000101101110 & Shared (with D10) \\
\hline D7 & 1001001000011011110 & Shared (with D188) \\
\hline D8 & 0100001000011011110 & Unique \\
\hline D10 & 0001001000101101110 & Shared (with D2) \\
\hline D16 & 0001001000101001110 & Unique \\
\hline D24 & 0011100100100111110 & Unique \\
\hline D84 & 0011001010010011101 & Unique \\
\hline D88 & 0101001001001011110 & Unique \\
\hline D96 & 0001001000011101110 & Unique \\
\hline D99 & 0001001000100011110 & Unique \\
\hline D125 & 0101001000101011110 & Unique \\
\hline D145 & 0101001011001001110 & Unique \\
\hline D148 & 0110001100111001110 & Unique \\
\hline D158 & 0001010101101011110 & Unique \\
\hline D159 & 0001000010100111110 & Unique \\
\hline D160 & 0011001010101011110 & Unique \\
\hline D162 & 0010001000101001110 & Unique \\
\hline D168 & 0101001000100111110 & Shared (with D197) \\
\hline D169 & 0100000100101011110 & Unique \\
\hline D172 & 0110010001100111101 & Unique \\
\hline D175 & 0010010001100011110 & Unique \\
\hline D188 & 1001001000011011110 & Shared (with D7) \\
\hline D189 & 1001001100010011110 & Unique \\
\hline D190 & 1001001000100011110 & Unique \\
\hline D197 & 0101001000100111110 & Shared (with D168) \\
\hline $\mathrm{DG}$ & 0001001001010111110 & Unique \\
\hline DS & 0101001001101011110 & Unique \\
\hline
\end{tabular}

2 Note: DG = Durian Gergasi; DS = Durian Siam 
Table 7 (on next page)

Summary of analysis of clonal status of nine durian types 
1 Table 7 Summary of analysis of clonal status of nine durian types

\begin{tabular}{clccccccc}
\hline \multirow{2}{*}{$\begin{array}{c}\text { Durian } \\
\text { type }\end{array}$} & $\begin{array}{l}\text { Sampling } \\
\text { locations }^{\mathrm{b}}\end{array}$ & DZ01 & DZ02 & DZ03 & DZ04 & DZ05 & DZ07 & DZ08 \\
\hline D2 & $\begin{array}{l}\text { PM, LP, BE, } \\
\text { BEA }\end{array}$ & Same & Different & Same & Same & Same & Same & Same \\
\hline D7 & $\begin{array}{l}\text { LP, 5L, BE, } \\
\text { BEA }\end{array}$ & Different & Same & Different & Same & Same & Same & Same \\
\hline D8 & LP, 5L & Same & Same & Same & Same & Same & Same & Same \\
\hline D24 & $\begin{array}{l}\text { PM, LP, 5L, } \\
\text { BE, BEA }\end{array}$ & Same & Same & Same & Same & Same & Same & Same \\
\hline D99 & PM, LP, 5L & Different & Different & Same & Different & Same & Same & Same \\
\hline D159 & LP, BE & Different & Same & Different & Different & Same & Same & Different \\
\hline D168 & PM, LP, 5L & Same & Same & Same & Same & Same & Same & Same \\
\hline D188 & LP, BE & Different & Different & Different & Different & Same & Same & Different \\
\hline D197 & PM, LP & Same & Same & Same & Different & Same & Same & Same \\
\hline
\end{tabular}

2 Note: ${ }^{b} \mathrm{PM}=$ Putra Mart, LP=Ladang Puchong, BE=Bukit Ekspo, BEA=Bukit Ekspo Plot A, $35 \mathrm{~L}=$ Ladang 5 .

4 